\title{
INDIAN NOTES AND MONOGRAPHS
}

EdITEd By F. W. Hodge

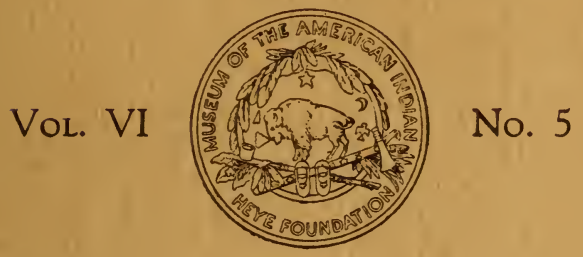

A SERIES OF PUBLICATIONS RELATING TO THE AMERICAN ABORIGINES

\section{BIBLIOGRAPHIC NOTES ON PALENQUE, CHIAPAS}

BY

\section{MARSHALL H. SAVILLE}

E

51

.1392

vol. 6

no. 5

NMAIREF

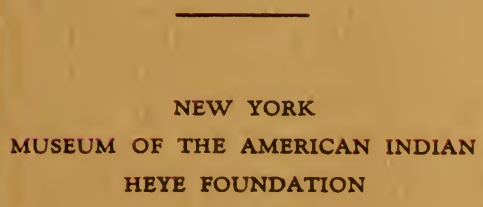

1928 
This series of Indian Notes AND MonoGRAPHS is devoted to the publication of the results of studies by members of the staff and by collaborators of the Museum of the American Indian, Heye Foundation, and is uniform with Hispanic Notes and Monographs, published by the Hispanic Society of America, with which organization this Museum is in cordial coöperation.

A List of Publications of the Museum will be sent on request.

\author{
Museum of the American Indian \\ HeYe Foundation \\ BROAdWAY AT 155Th St. \\ New YORK CITY
}




\section{INDIAN NOTES \\ AND MONOGRAPHS}

Edited By F. W. Hodge

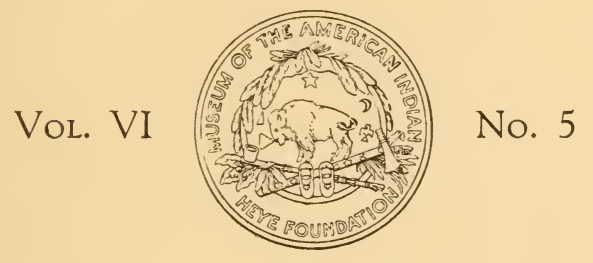

A SERIES OF PUBLICATIONS RELATING TO THE AMERICAN ABORIGINES

\section{BIBLIOGRAPHIC NOTES ON PALENQUE, CHIAPAS}

BY

MARSHALL H. SAVILLE

NEW YORK

MUSEUM OF THE AMERICAN INDIAN

HEYE FOUNDATION

1928 
LANCASTER PRESS, INC.

LANCASTER, PA. 


\title{
BIBLIOGRAPHIC NOTES ON PALENQUE, CHIAPAS
}

\author{
BY \\ MARSHALL H. SAVILLE
}

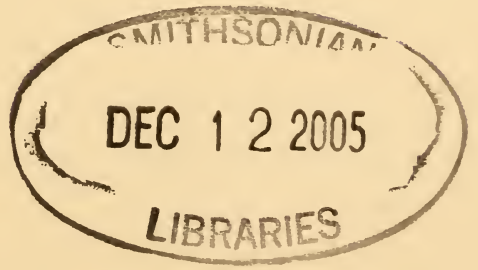





\section{BIBLIOGRAPHIC NOTES ON PALENQUE, CHIAPAS}

By Marshall H. Saville

DALENQUE ranks with Copan, Quirigua, and Tikal as one of the great achievements of the ancient Maya in city planning and building during the so-called Old Empire period of Mayan greatness. Owing to its isolated situation in the State of Chiapas, remote from lines of travel and corered with a dense tropical forest, until recent times it has been visited by few travelers, and like the majority of Old Empire cities, little intensive exploration has been done at the site. Rau in 1879 gave an excellent account of the progress of the earlier investigations here in his study of the Palenque Tablet, and much information is contained in the works of Stephens, Brasseur de Bourbourg, Bancroft, and Maudslay. The bibliographic notes of Bandelier are useful.

The ruined city of Palenque appears to have been unknown to the Spaniards until the middle of the 18th century. In 1773 they were first examined and critically reported on by Ordoñez y Aguiar. In 1784 the ruins were again visited and reported on by 


\section{B I B L I O G R A P H I C N O T E S}

José Antonio Calderón. The next year the survey was continued by the architect Antonio Bernasconi. The Royal Historiographer, Juan Bautista Muñoz, used both Calderón's and Bernasconi's reports in a memorandum addressed to José de Gálvez, dated 1786, now preserved, together with Bernasconi's pencil-drawings, in the British Museum. These two reports have been translated into French and published by Brasseur de Bourbourg (1866). In 1786 the work of exploration was continued by Antonio del Rio, and a report bearing his signature, dated Palenque, June 24, but partly in the handwriting of Muñoz, is included in the volume of manuscripts in the British Museum. Later investigators at Palenque include Dupaix, Castañeda, Waldeck, Stephens, Catherwood, Caddy, Charnay, Maudslay, Holmes, Maler, and Blom. Their works are referred to under the chronological entries which follow.

It is hardly necessary to state here that the city was abandoned by the Maya a number of centuries before the coming of the Spaniards in the 16th century. Stephens writes: "Cortez must have passed within twenty or thirty miles of the place now called Palenque. If it had been a living city, its fame must have reached his ears, and he would probably have turned aside from his road to subdue and plunder it. It seems reasonable to suppose that it was at that time desolate and in ruins, and even the memory of it lost." Our present knowledge of the 
import of the hieroglyphic inscriptions bears out Stephens' supposition, for correlation of the dates shows that more than a thousand years had passed since the city was abandoned.

While rank tropical growth which overspreads the city has perhaps done more than the hand of man to accomplish the ruin of the edifices, still vandalism has been rampant since their discovery. Del Rio (1822) writes that immense masses of stone ruins were to be seen in every direction, and in pursuance of his desire to explore the place, he "effected all that was necessary to be done, so that ultimately there remained neither a window nor a doorway blocked up, a partition that was not thrown down, nor a room, corridor, court, tower, nor subterranean passage in which excavations were not effected from two to three yards in depth, for such was the object of my mission." Dupaix (1834) removed several small stone slabs with hieroglyphs from the Palace. Two of these are now in the Museo Arqueológico Nacional in Madrid (figs. 2, 3), one is in the Museo Nacional of Mexico (fig. 1), and a fourth (fig. 4) has disappeared. (See pp. 132-136.)

Perhaps the most important building at Palenque, certainly the most famous, is the Temple of the Cross. This edifice formerly contained two sculptured stone tablets, one on each outer side of the doorway, but they were removed between the years 1807 , when they were seen in place by Dupaix, and 1832, the time of Waldeck's visit, when they were in 


\section{B I B L I O G A P H I C NOTES}

the modern village of Santo Domingo Palenque. For a long time they have been embedded in the front wall of the church in that village. In the socalled sanctuary of the temple, built against the back wall of the rear chamber, there were formerly three slabs forming the Tablet of the Cross. In 1840, at the time of Stephens' visit, only the first or left slab was in place. Stephens writes that the middle one had been removed many years before by one of the inhabitants of the village, and was lying near the bank of the Rio Michol which flows through the city. It was at that time drawn by the artist Catherwood. It later appeared in the Museo Nacional in Mexico, but just when it was carried there I have been unable to learn. The third slab, formerly the righthand section of the tablet, is said by Stephens to have been broken and unfortunately destroyed. "Most of the fragments have disappeared, but, from the few we found among the ruins in front of the building, there is no doubt that it contained ranges of hieroglyphics corresponding in general appearance with those of the stone on the left." Probably stimulated by the visit of Stephens, Mr. Charles Russells, United States consul at Laguna, who had entertained both Stephens and Catherwood, collected all the fragments of this slab and forwarded them to Washington, where they arrived in 1842, two years after Stephens' visit to the ruins. They were later placed in the Smithsonian Institution, where they remained until 1908, when, through the initiative of 
Elihu Root, Secretary of State, they were returned to Mexico and are now joined to the central slab. In the same year the Mexican Government caused the first slab to be removed, and the tablet is now preserved as an entity in the Museo Nacional.

\section{4}

Ordoñez y Aguiar, Ramón de. Memoria relativa á las ruinas de la ciudad descubierta en las inmediaciones del pueblo de Palenque, de la provincia de los Tzendales del obispado de Chiapa, dirigida al Ilm̄o. y R̄̄o. Señor Obispo desta diocesis.

Manuscript of $23 \mathrm{ff}$. copied from the original in the Museo Nacional of Mexico. Manuscript formerly successively in the libraries of Brasseur de Bourbourg and Pinart. It is preceded by all the documents relating to the ruins of Palenque in the library of the Real Academia de la Historia, Madrid.

Estacheria, José de. Expediente sobre el descubrimiento de una gran ciudad en la provincia de Chiapas, distrito de Guatemala. Nov. 28, 1784.

Manuscript in the archives of the Real Academia de la Historia, Madrid. Bandelier states that it is addressed to the Lieutenant Alcalde Mayor of Chiapas at Santo Domingo del Palenque, directing him to survey the ruins.

Calderóx, José Antonio. Informe fecho en 15 de Diciembre de 1784.

This report has been published in substance by Brasseur de Bourbourg. See entry under 1866. 


\section{8}

Juarros, Domingo. Compendio de la historia de la Ciudad de Guatemala. Guatemala. 2 vols.

In Tratado Primero, cap. I, Juarros gives the earliest traceable printed notice of the ruins. An abridgment of this work was published in London in 1823, being an English translation by J. Baily. A translation of what Juarros writes concerning Palenque follows:

"St. Domingo Palenque, a village in the province of Tzendales, on the borders of the intendencies of Ciudad Real and Yucatan. It is the head of a curacy; in a wild and salubrious climate, but very thinly inhabited, and now celebrated from having within its jurisdiction the vestiges of a very opulent city, which has been named Ciudad del Palenque; doubtless, formerly the capital of an empire whose history no longer exists. This metropolis,-like another Herculaneum, not indeed overwhelmed by the torrent of another Vesuvius, but concealed for ages in the midst of a vast desert,--remained unknown until the middle of the eighteenth century when some Spaniards having penetrated the dreary solitude, found themselves, to their great astonishment, within sight of the remains of what once had been a superb city of six leagues in circumference; the solidity of its edifices, the stateliness of its palaces, and the magnificence of its public works, were not surpassed in importance by its vast extent; temples, altars, deities, sculptures, and monumental stones bear testimony to its great antiquity. The hieroglyphics, symbols, and emblems which have been discovered in the temples, bear so strong a resemblance to those of the Egyptians, as to encourage the supposition that a colony of that nation may have founded the city of Palenque, or Culhuacan. The same opinion may be formed respecting that of Tulhá, the ruins of which are still to be seen near the village of Ocosingo in the same district." 


\section{ON PALENQUE}

\section{0}

Humboldt, A. von. Vues des cordillères, et monumens des peuples indigènes de l'Amérique. Paris. Text and atlas in one volume.

On pl. 11 is represented a "relief Mexicaine trouvé à Oaxaca," which in reality is the stucco bas-relief on one of the eastern piers of the Palace at Palenque. Humboldt writes that the sketch was turned over to him by the Mexican naturalist Cervantes, with the statement that the person who sent the drawing to Cervantes assured him that it was copied with the greatest care; and that the relief, sculptured on a blackish and very hard rock, was more than a meter in height. This is the earliest published illustration of the Palenque ruins, but the drawing in Humboldt's work does not correspond to those published as a result of the Del Rio and Dupaix explorations. It is probably either from the Calderón or the Bernasconi drawings made respectively in 1784 and 1785 , which seem not to have been published.

\section{2}

Cabrera, Dr. Paul Felix. Description of the ruins of an ancient city, discovered near Palenque, in the Kingdom of Guatemala in Spanish America: translated from the original report of Captain Don Antonio del Rio. Followed by: Teatro Critico Americano, a critical investigation and research into the history of the Americans by Doctor Felix Cabrera of the city of Guatemala. London.

The report on the ruins (pp. 1-22) by Del Rio to Don José Estacheria is dated Palenque, June 24, 1787 (a misprint for 1786). At the end are 17 unnumbered 


\section{B I B L I O G R A P H I C NOTES}

plates, some of which are signed J. F. W. or F. W., the initials of Frederick Waldeck, the lithographer, who ten years later went to Palenque and spent more than a year at the ruins.

Two German translations of the work of Del Rio were soon issued. The titles are: (1) Huehuetlalpallan, Amerika's grosse Urstadt in dem Königreich Guatimala. Neu Entdeckt vom Capitain Don Antonio del Rio, etc., translated by H. Berthoud, mit 17 grossen Zeichnungen in Steindruck, Meiningen, 1823; (2) Beschreibung einer alten Stadt, die in Guatimala, etc., translated by J. H. von Minutoli, mit 14 lithogr. Tafeln; Berlin, 1832.

\section{3}

BAILY, J., trans. See JuARros (1808).

\section{5}

Warden, David B. Description des ruines découvertes près de Palenqué. Recueil de Voyages et Mémoires publiés par le Société de Géographie, Paris, tome II, pp. 170-193, pls. v, xiv-xviii.

The greater part of this article was abstracted from the work of Cabrera (1822).

\section{$1830-1848$}

KING, Edward, Lord Kingsborough. Antiquities of Mexico; comprising fac-similes of ancient Mexican paintings and hieroglyphics ... London. 9 vols.

The report of the third expedition to the ruins of Palenque, made by Dupaix in 1807, is included by Lord Kingsborough in this monumental work.

The plates are in vol. IV, pt. III, nos. 9-43. The descriptive text, being the report in Spanish, is in vol. r, pp. 294-339, and an English translation is in vol. vi, pp. $473-483$. 


\section{1}

Galindo, Juan. [Letter.] London Literary Gazette and Journal of Belle Lettres, Arts, Sciences, no. 769, London.

This article was published also in French. See entries dated 1832 and 1833.

\section{2}

Corroy, $D r$. François. Extrait d'une lettre [sur son voyage à Palenque]. Bulletin de la Société de Géographie, Paris, tome 18, no. 111, pp. 54-56.

This is a portion of a letter, dated November 10, 1831, written from Tabasco by a French physician resident in that state for a number of years. He describes Palenque. It appears that he made several visits to the ruins.

Cochelet, Adrien. Sur les monumens de Palenqué, dans l'Amérique centrale, et-sur les routes qui conduisent de Mexico à Guatemala. Lettre de M. Cochelet, consul général et chargé d'affaires de France près le gouvernement de la république de l'Amérique centrale. Ibid., no. 114, pp. 189197.

See also this author's Lettre à M. Jomard, ibid., tome 17, no. 106, pp. 101-108, Février 1832.

Galindo, Juan. [Sur les ruines de Palenque.] Mémoire adressé à M. le secrétaire de la Société de géographie de Paris. Ibid., pp. 198-214, folded pl. with 12 figs.

The figures on the folded plate are: 1, Profil des galeries; 2, Grand entrée centrale du palais; 3, Plan du 
palais; 4, Figure de la façade du palais; 5 , Tête au dessus de l'un des passages des souterrains; 6, Figure gigantesque dans la cour du palais; $7,8,10$, Se trouvent dans cette même position relative; 11 , Est au dessus de la fig. no. 12. The last six figures are of glyphs. On pp. 212-214 is a brief discussion of the Maya language, with texts and a short vocabulary. The letter is dated "Ruines de Palenqué, 27 avril," presumably the year 1831; it was translated into English, and published in the London Literary Gazette in the year named.

\section{3}

Galindo, Juan. Description of the river Usumasinta, in Guatemala. Journal of the Royal Geographical Society, vol. III, pp. 59-64, London.

The ruins of Palenque are merely mentioned; but in a footnote (pp. 60-61) is reprinted the account of the ruins by Galindo, published in the London Literary Gazette for 1831.

\section{4}

Galindo, Juan. A short account of some antiquities discovered in the district of Peten, in Central America: in a Letter from Lieutenant-Colonel Juan Galindo, governor of Peten, addressed to Nicholas Carlisle, Esq., F. R. S., secretary. In Archceologia, or Miscellaneous Tracts Relating to Antiquity, published by the Society of Antiquaries of London, vol. xxv, pp. 570-571, pls. lix-lxx.

The communication was written from Flores, Peten, and bears the date October 28, 1831. Galindo figures (pl. lix) four stucco glyphs from the façade of what he called the "study," the building now known as the 
Temple of the Inscriptions. One of these glyphs is now in the Musée du Trocadero, Paris, and has been illustrated by Hamy. See entry under 1897.

Dupaix, Guillelmo. Antiquités méxicaines. Relation de trois expéditions du Capitaine Dupaix, ordonnées en 1805,1806 , et 1807 , por la recherche des antiquités du pays ... accompagnée des dessins de Castañeda . . suivi d'un parallèle de ces monuments avec ceux . . . de l'ancien monde par A. Lenoir, etc. Paris. 2 vols.

Captain Dupaix went to Palenque in December, 1807 , on his third archeological expedition in Mexico, but the explorations were carried on during the following year. The plates of Castañeda's drawings are xi to xlvi; the text relating to the expedition, in the section Antiquités Méxicaines, première partie, occupies pp. 3-40, Dupaix's report being pp. 3-36. In "Notes et documents divers," no. 1, pp. 3-6, is an "Extrait du voyage d'Antonio Del Rio aux ruines de Palenque en 1787." In no. 10, pp. 67-75, is "Notions transmises par M. Juan Galindo sur Palenque et autres lieux circonvoisins," followed in the deuxième partie by "Examen des planches de la troisième expédition du Capitaine Dupaix par Alexandre Lenoir," pp. 73-81, pls. xi-xlvi, and supplementary pl. iii (after Humboldt, see under 1810). These plates are in the volume devoted to plates.

The report of Dupaix is included in the work of Lord Kingsborough (1830-1848), vol. v, pp. 207-343, London, 1831. A review by M. Jomard in Bull. Soc. de Géogr. de Paris, t. 18, no. 114, pp. 218-220, Oct. 1832, evidently refers to this.

In the report by Del Rio (1822) are drawings of two small stone tablets, each containing an inscription of six glyphs. In the Dupaix work these are illustrated in lithography, preceded by a third, given respectively 


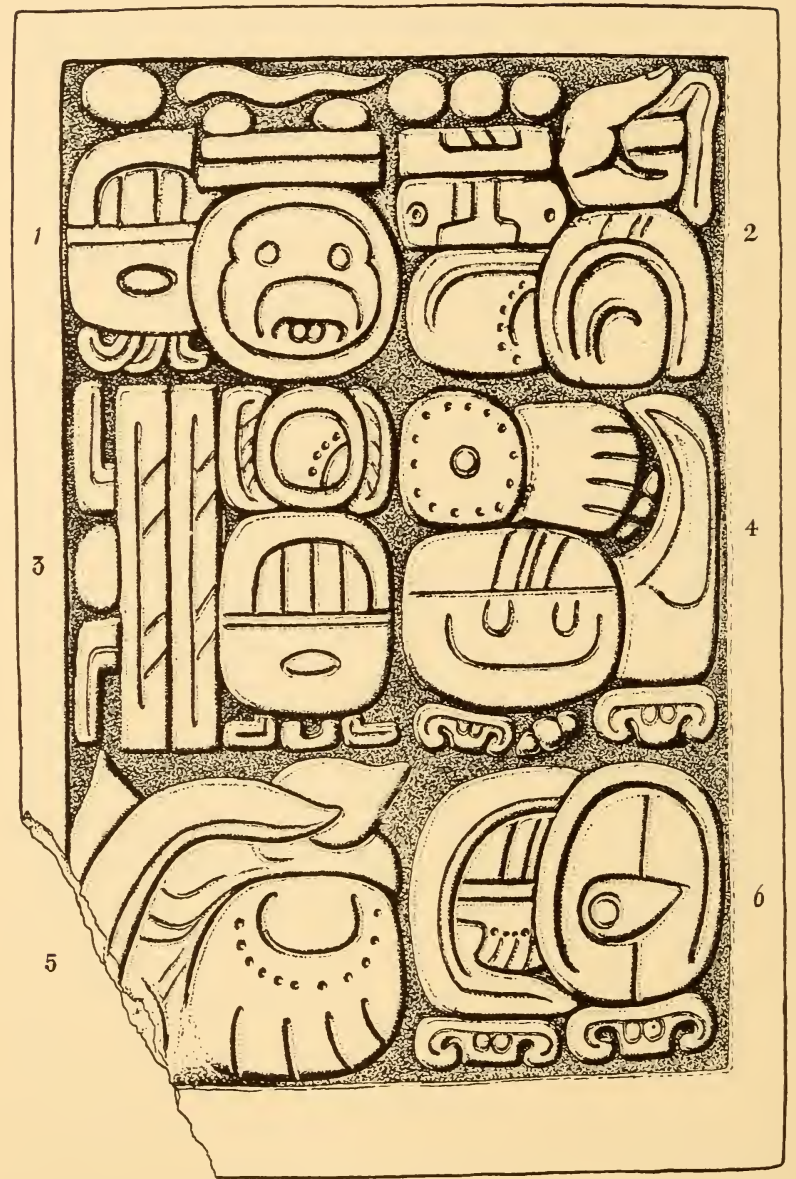

FIg. 1.-Tablet I, Museo Nacional de Arqueología of Mexico. 


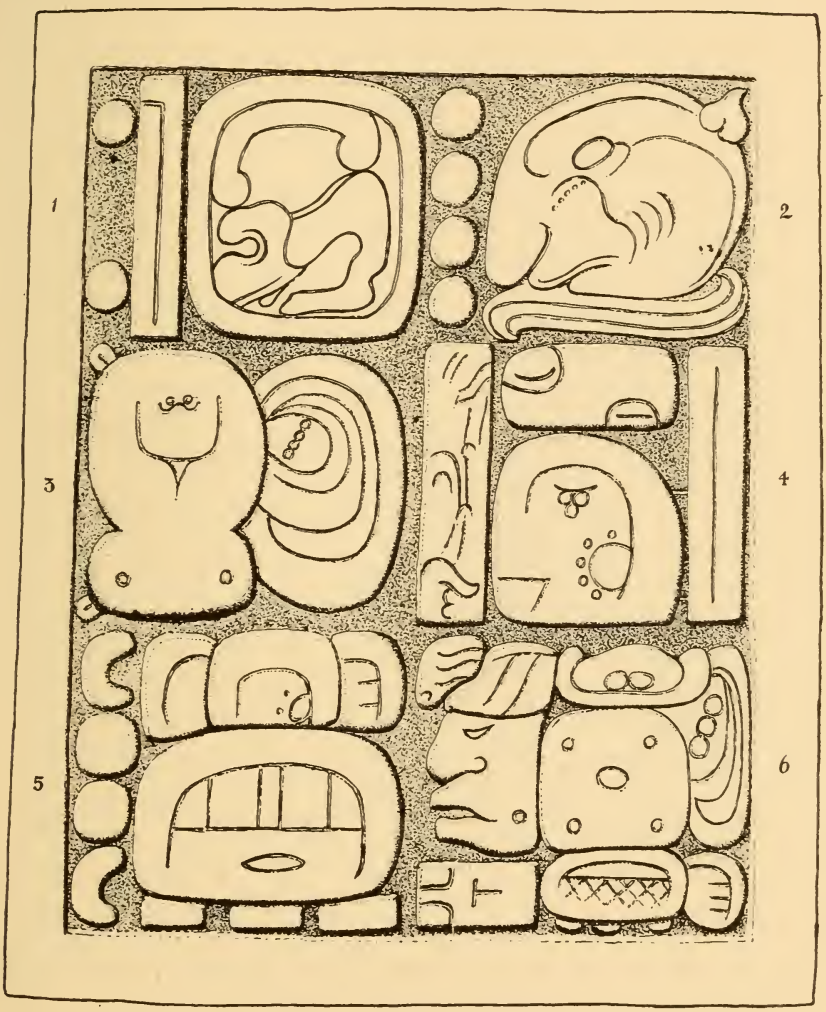

FIG. 2.-Tablet II, Museo Arqueológico Nacional in Madrid. 


\section{B I B L I G R A P H I N T E S}

in pls. 39-41. There is a fourth similar tablet, now in Madrid, which has never been illustrated. The published drawings of the first three tablets are far from accurate, and I have therefore had new drawings made, correcting inaccuracies, and with a single exception have been able to restore glyphs almost unrecognizable as originally delineated. Tablet I has been drawn directly from a cast from a mold made by Le Plongeon; Tablet III is from a not too distinct photograph made for me in 1912 and from sketches made by me; Tablets II and IV contain well-known glyphs found repeatedly in the inscriptions at $\mathrm{Pa}$ lenque, and the corrections have been made from the drawings by Miss Hunter, published by Maudslay (1896-1902). Tablet II was also sketched by the writer in Madrid.

Tablet $I$. This tablet is illustrated by Dupaix in pl. 39 and by Lord Kingsborough in pl. 23. It has long been in the Museo Nacional de Arqueología of Mexico. It is 15 inches high and about 9 inches wide, the other three tablets being practically of the same dimensions. Both Le Plongeon and Charnay made molds and casts of this slab, Charnay casts being exhibited in several museums. The drawing (fig. 1) is from a cast from the Le Plongeon mold in possession of the writer. This slab was discovered by Dupaix in a subterranean chamber of the Palace. He writes that, after exploring the various corridors, "we therefore ascended by a different staircase, affording an egress near an angle of the building, on the landing place of which I discovered a stone, which I have preserved as a curious relic. This stone, being strongly embedded in the wall, was removed with difficulty." The lower left-hand corner of the tablet is missing, probably having been broken off in the work of taking it out of the wall.

Tablet I presents many glyphs easy of decipherment. Glyph 1 is a combination of two characters. The section at the left is the sign for the year of 360 days called tun. Above is a dot, the sign for 1 , showing a count of 1 Tun. The other section is a day- 


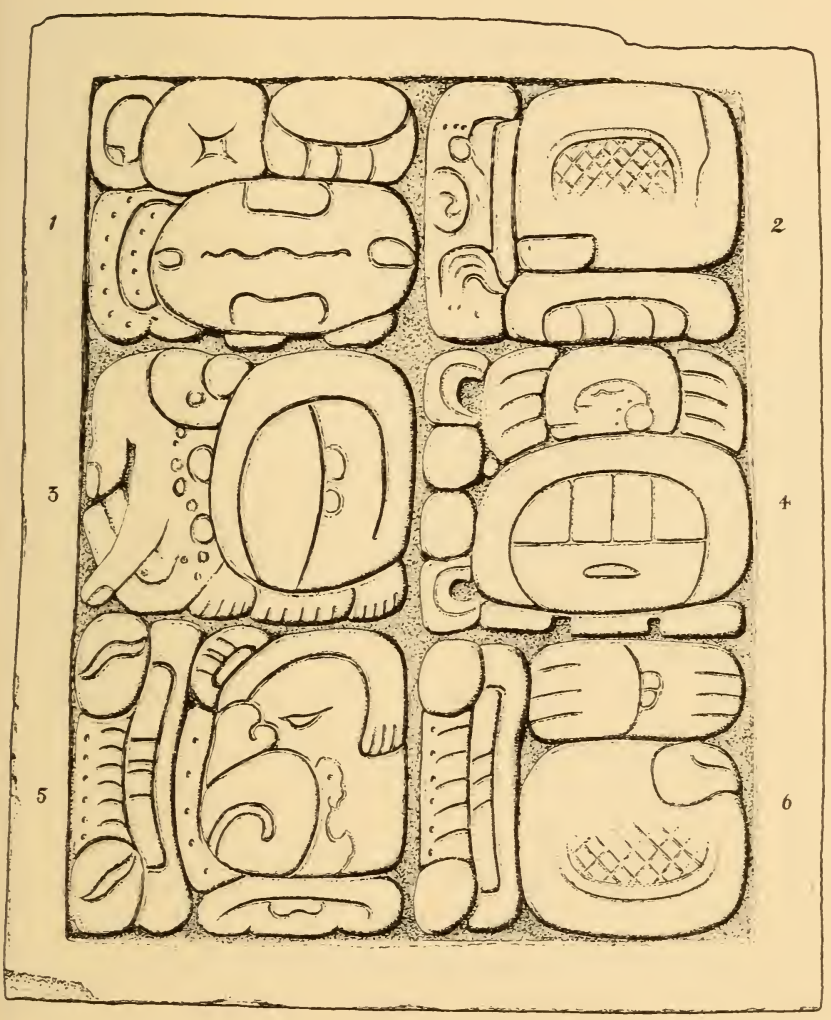

FIG. 3.-Tablet III, Museo Arqueológico Nacional in Madrid. 


\section{B I B L I O G R A P H I C NOTES}

sign, ahau, the two bars and two dots designating the number 12, hence the day 12 Ahau. The small serpent-like object above is frequently found in Mayan inscriptions, and Bowditch has given the name "Ahau with serpent" to this glyph. Glyph 2 of the left-hand section seems to be the month 7 Ceh. The right-hand section shows the well-known hand sign. Glyph 3 is the sign for a katun, a period of 20 times a year of 360 days, or 7200 days; hence 11 katuns or 79,200 days are expressed. The other glyphs have not yet been deciphered, with the exception of the right-hand section of glyph 5, which seems to represent the sign for the day Imix.

Tablet II. This tablet, which is illustrated by Del Rio (pl. 15), Dupaix (pl. 40), and Lord Kingsborough (pl. 42), is now in the Museo Arqueológico Nacional of Madrid. The drawing (fig. 2) is based on Dupaix, aided by a sketch by the writer. Glyphs 1 and 2 represent dates. Glyph $1 \mathrm{I}$ am inclined to identify as the day Oc preceded by the conventional sign for the number 7 expressed by a bar (5) and two dots, making the number 7 . It might also be either the day Cimi or Eb. The glyph following (no. 2) certainly expresses the month 4 Xul. Further study of this inscription should reveal the true character for the day. In glyph 5 are represented a count of 14,400 days. Glyphs 4 and 6 are common at this site, but glyph 3 is rather unusual. The left-hand section of glyph 6 may be a face numeral.

Tablet III has never before been illustrated. Our reproduction (fig. 3) is based on a photograph and a sketch by the writer. The slab is now in the Museo Arqueológico Nacional of Madrid. The six glyphs are all found in one form or another at Palenque. In glyph 4 we find 2 katuns or 14,400 days expressed. The number 7 is certainly indicated in glyphs 5 and 6 , but the main part of glyph 5 bears a strong resemblance to the glyph representing the north.

Tablet IV. This tablet is illustrated by Del Rio (pl. 16), Dupaix (pl. 41), and Kingsborough (pl. 42). 
Its present provenience is unknown to the writer. The drawing, fig. 4 , is based on Dupaix, corrected by a study of the inscriptions of Palenque published by Maudslay. In this slab the arrangement of the glyphs is different from that on the other three tablets, being placed in two lines of three glyphs

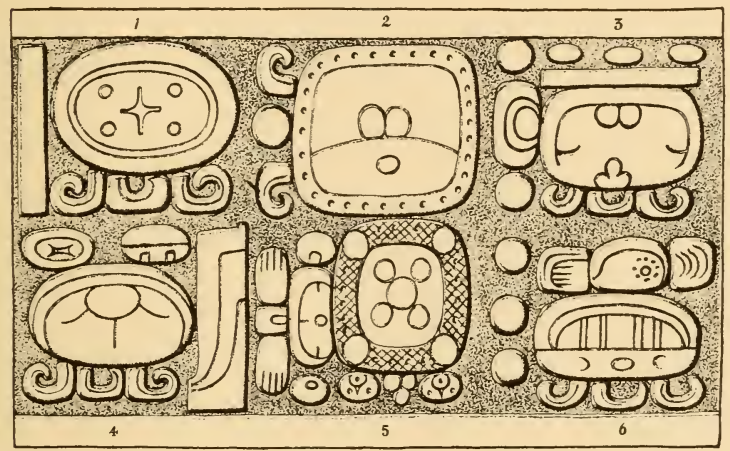

FIG. 4.-Tablet IV, present location unknown.

instead of three lines of pairs. Glyphs 1 and 2 occur frequently in the long inscription of the Temple of the Inscriptions, being apparently the date 5 Lamat 1 Mol. Glyph 3 is the sign for the month called Uinal, consisting of 20 days. The conventional sign for the number 8 indicates 8 times 20, or 160 days, to which must be added two single days as shown by the two dots at the left, making a total of 162 days expressed by the glyph. Glyph 4 is the unrecognizable one referred to above; and from the drawing I have been unable to find a similar glyph in the Palenque inscriptions. Above are two small characters, the wellknown sign ik ben. Probably one could find its 


\section{B I B L I G R A P H I C N O T E S}

counterpart in Palenque by a study of the original tablet if it could be found. Glyph 5 is very common at Palenque, but its import is not known. The last glyph, number 6 , is the character for the katun, the period of 7200 days. The numeral 3 at the left indicates a count of 21,600 days.

\section{5}

Bustamante, Miguel. Observaciones sobre el dibujo de un relieve de Palenque remitido al Museo Nacional por el Sr. Waldeck. Revista Mexicana, Mexico, tomo I, no. 4, pp. 498-500.

\section{7}

Gondra, I. R. Antiguedades mexicanas. Extracto del viage de $\mathrm{D}$. Antonio del Rio, a las ruinas del Palenque en 1797. El Mosaico Mexicano, Mexico, tomo II, pp. 330-334, 1 pl.

The illustration presents a view of the palace.

\section{8}

WALDECK, Frederick. Voyage pittoresque et archéologique dans la province d'Yucatan (Amérique centrale), pendant les années 1834 et 1836. Paris.

In pl. xviii, fig. 3 , of this folio is illustrated a human head in stucco from a cornice in the "Temple of the Dead." In pl. xxii is a drawing of the stucco decoration over one of the openings to the subterranean chambers of the Palace, described on pp. 105-106.

According to Brasseur de Bourbourg, Waldeck arrived in Palenque on May 12, 1832. He left there some time during 1833 , for in the first paragraph of his 
Voyage Pittoresque he states that on December 5, 1833, cholera morbus broke out in Frontera, so that he could not return to Palenque. Hence he continued his voyage (probably from Vera Cruz) to Yucatan, via Campeche, although Brasseur de Bourbourg states that he [Waldeck] spent three entire years at Palenque.

\section{0}

Caddy, John Herbert. The City of Palenque. [Manuscript report on explorations made in Palenque early in 1840.] $36 \mathrm{pp}$. with portfolio, $15 \times 21$ inches, containing a plan of the palace, 24 sepia paintings of buildings and sculptures, a folding map of the peninsula of Yucatan, and a sketch map of the ruins.

Stephens and Catherwood made their first trip to Middle America in the autumn of 1839 . While in Belize, British Honduras, they met Mr. Patrick Walker, secretary of the Colonial government, and Captain John Herbert Caddy, of the British Royal Artillery. These two gentlemen made an expedition to Palenque two or three months later, and Stephens writes that while he was at Guatemala City in April, 1840 , he received word from Lieutenant Nichols, aidede-camp of Colonel MacDonald who had just arrived from Belize, that they had set out for Palenque by way of the Belize river, but had been speared by the Indians. The two American explorers arrived at Palenque late in the spring, and Stephens states that when he reached the village of Santo Domingo de Palenque, the prefect of the town told him that he had been expecting his arrival for some time, as Don Patricio had told him that he was coming. He soon learned that Don Patricio was Mr. Walker. Stephens continues: "This was the first notice of Mr. Walker and Captain Caddy I had received since Lieutenant Nichols brought to Guatemala the report that they 


\section{B I B L I O G R P H I C N O T S}

had been speared by the Indians. They had reached Palenque by the Belize river and Lake Peten, without any other difficulties than from the badness of the roads, had remained two weeks at the ruins, and left for the Laguna and Yucatan."

Captain Caddy, who was an artist of no mean ability, drew some plans of the ruins and made a number of remarkable sepia sketches of buildings and sculptures. On his return to England he carefully finished the plans and sketches with the idea of publishing a work. A note written on the manuscript report which he prepared states that he read it before the Society of Antiquaries in London on January 13, 1842 , but I find no record of the reading in the publications of the Society. The prompt appearance in 1841 of the results of the investigations of Stephens and Catherwood, before Captain Caddy had time to complete his own report, forestalled the publication of Captain Caddy's investigations, and it has therefore remained in manuscript, unknown to students. In the spring of $1923 \mathrm{I}$ had the good fortune to meet in New York, Miss Alice Caddy, granddaughter of Captain Caddy, from whom I learned of the existence of this work in possession of her father, a resident of Ottawa. Through the kindness of Miss Caddy, the manuscript and portfolio have been placed in my hands for publication.

The portfolio contains some sketches not found in Stephens' work, and a number of the drawings are more accurate than those of Catherwood. While it adds but little to our knowledge of the ruins, owing to investigations by later explorers equipped with cameras, yet the artistic quality of Captain Caddy's work merits its publication; indeed it is highly important to thus record the results of all pioneer researches, as the ruins have deteriorated considerably since the early years of the last century. 
1841

Stephens, John Lloyd. Incidents of travel in Central America, Chiapas, and Yucatan. New York. 2 vols.

The account of Palenque appears in vol. II, pp. 280$365,32 \mathrm{pl}$. Stephens and Catherwood were at Palenque late in the spring of 1840 .

\section{4}

Catherwood, Frederick. Views of ancient monuments in Central America and Yucatan. London. (Also New York.)

In the introduction to this folio (pp. 6-7) there is a brief notice of Palenque, calling attention to pls. 6 and 7. Pl. 6 is a general view of the ruins; pl. 7 consists of two views, the upper being the "principal court of the Palace," while the lower picture shows the interior of House 3 of the Palace.

\section{4}

Stephens, John Lloyd, and Catherwood, Frederick. Incidents of travel in Central America, Chiapas, and Yucatan. By the late John Lloyd Stephens. Revised from the latest American edition, with additions, by Frederick Catherwood. London.

The account of Palenque is in chapters xxxiixxxviii, pp. 399-480, ill. 45-76. The plates in this single-volume edition of Catherwood are from revised drawings, most of the illustrations, at least, being newly drawn. 


\section{7}

Morelet, Arthur. Voyage dans l'Amérique centrale, l'ile de Cuba et le Yucatan. Paris. 2 vols, with maps and engravings.

Morelet visited Palenque in 1847 , and describes the ruins in vol. I, chap. X, pp. 245-285. See entry under 1871.

\section{3}

Charnay, Désiré. Cités et ruines américaines. Mitla, Palenqué, Izamal, Chichen-Itza, Uxmal. Recueillies et photographiées par Désiré Charnay avec une texte par M. Viollet-le-Duc. (With atlas of plates.) Paris.

The ruins of Palenque are briefly treated by Violletle-Duc under the title "Antiquités Américaines" (pp. 72-74), from a study of the photographs and notes made by Charnay. Charnay describes the ruins in the section "Le Mexique 1858-1861, Souvenir et Impressions de Voyage," chap. xiii, pp. 411-441.

The atlas is an oblong folio of 7 pp. and 49 pls. Pls. 19-22 are of Palenque.

\section{5}

WaLdeck, Frederick. Description du bas-relief de la croix, dessiné aux ruines de Palenque en 1832. Revue Américaine, Paris, deuxième série, tome II, pp. 69-88, pl. 2.

The folded plate illustrates the tablet of the Temple of the Cross, drawn by Waldeck. 


\section{6}

Waldeck, F. DE, and Brasseur de Bourbourg, Charles Étienne. Recherches sur les ruines de Palenqué et sur les origines de la civilisation du Mexique. Par M. l'Abbé Brasseur de Bourbourg. Text publié avec les dessins de M. de Waldeck sous les auspices de S. E. M. le Ministre de l'Instruction Publique. Paris. (Avant-propos, xxiii pp.; Introduction, pp. 1-27; Recherches sur les ruines de Palenqué et sur les origines de l'ancienne civilisation du Mexique, pp. 29-84.)

Monuments anciens du Mexique. Palenqué et autres ruines de l'ancienne civilisation du Mexique. Collection de vues, bas-reliefs, morceaux d'architecture, coupes, vases, terre cuites, cartes et plans. Dessines d'aprés nature et relevés par M. de Waldeck. Texte rédigé par M. Brasseur de Bourbourg. Ouvrage publié sous le auspices de S. E. M. le Ministre de l'Instruction Publique, viii pp., 56 pl. Paris.

Forty of these splendid lithographic plates reproduce Waldeck's drawings made at Palenque.

\section{6-1867}

Brasseur de Bourbourg, Charles Étienne. Découverte et explorations des ruines de Palenque. Revue Américaine, Paris, première année, nos. 1-2, Nov. 1866, Jan. 1867.

This is the introduction of the large work. See entry under 1866. 


\section{B I B L I O G R A P H I C N O T E S}

Viollet-le-duc, Eugène Emanuel. Ciudades y ruinas Americanas. Mitla, Palenque, Izamal, Chichen Itza, Uxmal. Recogidas y fotografiados por Desire Charnay con un texto por M. Viollet-le-Duc arquitecto del gobierno. Obra dedicada a S. M. Napoleon III. Traducida del Frances por José Guzman. Mexico.

A translation by José Guzman of Antiquités Américaines, 1863. Palenque is described on pp. $45-46$.

\section{1}

Morelet, Arthur. Travels in Central America including accounts of some regions unexplored since the conquest. From the French of the Chevalier Arthur Morelet by Mrs. M. F. Squier. With introduction and notes by E. Geo. Squier. New York.

In this English translation of the travels of Morelet, an abstract only, the description of Palenque comprises chapter ii, pp. 65-111, 2 ills. Morelet spent a fortnight at the ruins in April, 1846. See entry under 1857.

A German translation of Mrs. Squier's edition was published in Jena in 1872 under the title, Reisen in Central-Amerika, von Arthur Morelet. In deutscher Bearbeitung von Dr. H. Hertz. viii-362 pp., map and plates.

\section{7}

Boddam Whetham, J. W. Across Central America. London.

Boddam Whetham made his journey to Central America in 1875. He describes his trip to Palenque on 
pp. 326-336. "After a trip to the ruins, one feels that modern life here is a sorry burlesque on that ancient Indian civilization which lies buried in the thick forest on the other side of the green valley. . . . Concerning the strange race of beings who inhabited the city how little is known! who they were and whence they came is mere conjecture, whither they went when they quitted their homes is wrapped in mystery. They disappeared as completely as did the blind CEdipus, when he wandered into the sacred woods of the Eumenides and was never heard of or seen again."

\section{9}

Rau, Charles. The Palenque tablet in the United States National Museum, Washington, D. C. Smithsonian Contributions to Knowledge, vol. xxil (Smithsonian Pub. 331), Washington. 76 pp., 2 pl., 17 fig.

This study includes an account of the various explorations made at Palenque, with descriptions of the Temple of the Cross, and of the famous tablet of the Cross made up of three slabs, of which the last section was at that time in the National Museum at Washington. Rau gives the history of this tablet, with an attempt at interpretation, but his study was conducted before much progress had been made in determining the true character of the inscriptions, although he nears the mark when he states, "I venture to suggest that its inscription constitutes a chronological record of some kind."

Translated into Spanish and published under the title, Tablero del Palenque en el Museo Nacional de los Estados Unidos, in Anales del Museo Nacional, tomo II, entrega 3, Mexico, 1880.

Also translated into French: La Stèle de Palenque, and published in Annales du Musée Guimet, tome x, Paris, 1884. 
Maler, Teobert. Nouvelles explorations des ruines de Palenque. La Nature, Paris, $7^{\mathrm{e}}$ ann., $2^{\mathrm{e}}$ sem., pp. 299-302.

\section{0}

Morgan, Lewis H. A study of the houses of the American aborigines; with suggestions for the examination of the ruins in New Mexico, Arizona, and the valley of the San Juan, and in Yucatan and Central America. Archæological Institute of America, First Annual Report of the Executive Committee, 1879-1880. Cambridge.

The above study occupies pp. 27-80. In it Mr. Morgan attempts to show, based chiefly on the grouping of the ruins of Uxmal, but also considering Palenque (pp. 74-77), that the ruined cities of Yucatan and Central America are to be classed as communal structures, "joint-tenement houses of the aboriginal American type."

RICE, Allen Thorndike. Ruined cities of Central America. North American Review, New York, vol. CCLXxxv, pp. 89-108, August.

An introduction by the editor of the North American Review to a series of articles by Désiré Charnay describing his explorations among the ruined cities of Mexico and Central America in 1880-1882. This expedition was under the auspices of the French Government and of Mr. Pierre Lorillard, who defrayed the greater part of the expense. Several of the buildings of Palenque are described by Rice on $\mathrm{pp}$. 103-107. The articles by Charnay commenced in September, 1880, and continued through eleven numbers. Those devoted to Palenque appeared in 1881. 
Charnay, Désiré. Mes découvertes au Mexique et dans l'Amérique du Centre. Tour du Monde, Paris, tome XLII, pp. 323-336, 12 ill.

For a Spanish translation see entry under 1884.

\section{1}

Morgan, Lewis H. Houses and house-life of the American aborigines. Contributions to North American Ethnology, vol. IV, Washington.

This is an extended study, of which the entry under 1880 is simply a specially prepared article. Chapter ix, pp. 251-276, cover the "Ruins of houses of the sedentary Indians of Yucatan and Central America." The same arguments are adduced to prove the communal character of the Middle American ruins. Palenque is treated on pp. 268-269.

Bandelier, Adolphe F. Notes on the bibliography of Yucatan and Central America; comprising Yucatan, Chiapas, Guatemala (the ruins of Palenque, Ocosingo and Copan), and Oaxaca (ruins of Mitla). A list of some of the writers on this subject from the sixteenth century to the present time. From Proceedings of the American Antiquarian Society, Worcester, Oct. 21, 1880.

On pp. 19-22 Bandelier devotes a section to "documents relative to the exploration of Palenque."

Charnay, Désiré. The ruins of Central America. North American Review, New York, pt. viI, pp. 491-496, March; pt. ViII, pp. 578-584, April. 
In these articles Charnay describes his explorations at Palenque. The definitive account will be found in the French and English narratives published in 1885 and 1887. See RicE (1880).

\section{2}

DE Rosny, Leon. Les documents écrits de l'antiquité américaine. Compte-rendu d'une mission scientifique en Espagne et en Portugal. Mémoires de la Société d'Ethnographie, no. 3, Paris.

In pl. 3, opposite p. 74 , de Rosny illustrates a beautiful bas-relief in stone from the ruins of Palenque, in the Museo Arqueológico Nacional de Madrid. It is wrongly captioned as being Yucatecan. See our fig. 5.

Bancroft, Hubert Howe. The works of Hubert Howe Bancroft. Vol. IV, The Native Races: vol. IV, Antiquities. San Francisco.

A résumé (pp. 289-346) describing the ruins, based on the works of various explorers, with illustrations. Valuable for its bibliographic notes.

\section{3}

Catalogue de la collection archéologique provenant des fouilles et explorations de M. Désiré Charnay au Mexique et dans l'Amérique centrale pendant les années 81 et 82 . Exposée provisoirement dans le palais du Trocadéro. Paris.

On pp. 9-10, illustrations $34-44$ and 46-61 are from casts of Palenque sculptures. 


\section{ON P A L ENQ UE}

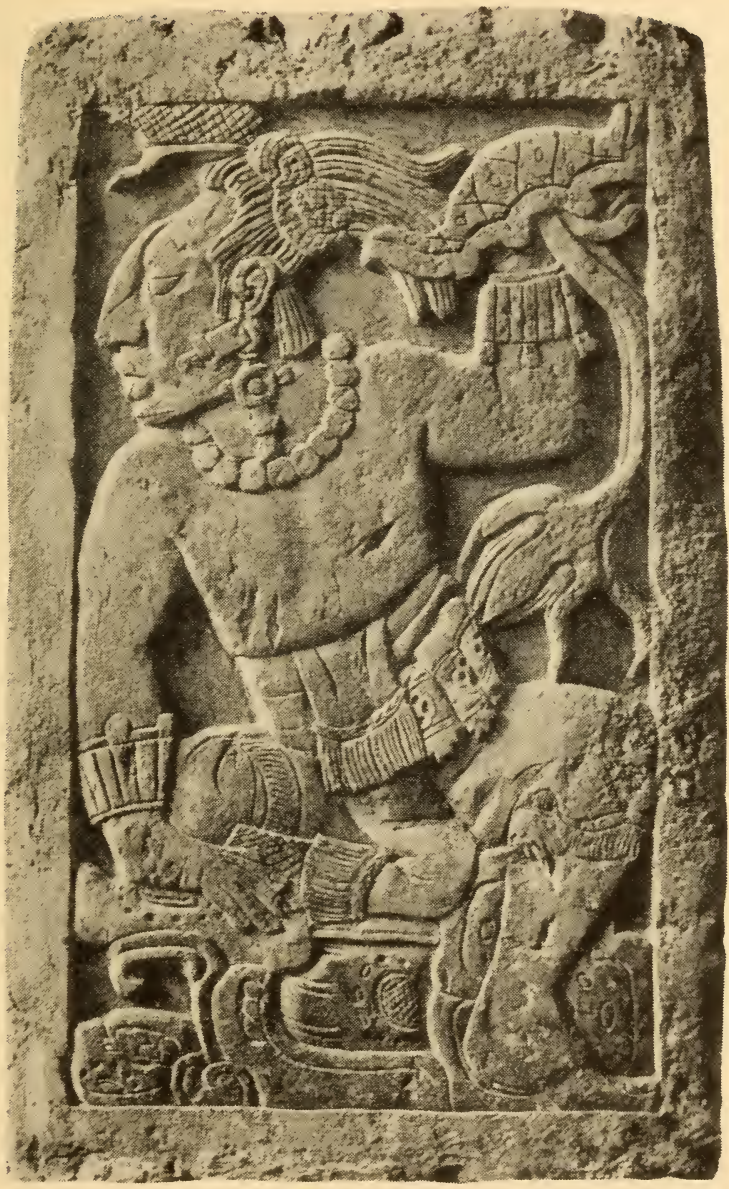

FIG. 5.-Stone tablet from Palenque in the Museo Arqueológico Nacional, Madrid. 


\section{4}

OBER, Frederick A. Travels in Mexico and life among the Mexicans. San Francisco.

It does not seem probable from the text that Ober visited Palenque, but chap. IX is devoted to "Palenque and the phantom city." See pp. 155-172, with 6 illustrations after Stephens.

Charnay, Désiré. Mis descubrimientos en Mexico y en la America Central. America Pintoresco, Barcelona, pp. 322-340, 11 ill.

This is a translation of the narrative published in Tour du Monde, 1880.

Maler, Teobert. Mémoire sur l'Etat de Chiapa, Mexique. Revue d'Ethnographie, Paris, tome III, num. 4, July-August.

Maler describes his first visit to Palenque in 1877 when he spent three weeks there. See pp. 322-336, and figs. 131-132.

\section{5}

Thomas, Cyrus. Palenque visited by Cortez. Science, New York, vol. v, no. 108, pp. 171-172, Feb. 27.

This short paper is based on Maler's report [1884] in which he expresses the belief that Palenque answers the description of one of the inhabited places visited by Cortés in 1525 , when he made his famous overland march to Honduras.

Brinton, Daniel Garrison. Did Cortes visit Palenque? Ibid., vol. v, no. 112, p. 248, Mar. 27. 


\section{ON P A L E Q UE}

Charnay, Désiré. Les anciennes villes du nouveau monde. Voyages d'exploration au Mexique et dans l'Amérique centrale par Désiré Charnay. 1857-1882. Paris.

Palenque, pp. 179-218, 27 ill.

\section{7}

Charnay, Désiré. The ancient cities of the New World. Being voyages and explorations in Mexico and Central America from 1857-1882. Translated from the French by J. Gonino and Helen S. Conant. New York.

Palenque, pp. 211-261, 27 ill. See notice of the last expedition under Rice (1880).

\section{8}

Rochefoucauld, F. A. de la. Palenqué et la civilisation Maya. Paris.

\section{9}

Polakowsky, H. Prähistorische Stadt bei Palenque. Internationales Archiv für Ethnographie, Leiden, Bd. II, p. 229.

\section{0}

Peñafiel, Antonio. Monumentos del arte Mexicano antiguo. Berlin. 3 vols.

In vol. I of the plates, pls. 142-143 comprise three drawings of Palenque reliefs. Pl. 144 is a splendid photograph of the panel illustrated in our fig. 1 . 11 


\section{1}

Grosse, Ernst. Gegenstände aus Palenque. Internationales Archiv für Ethnographie, Leiden, Bd. IV, pp. 164-165, 204-205, pl. xiv with 10 ills. of pottery (mostly fraudulent).

\section{2}

Thomas, Cyrus. A brief study of the Palenque tablet. Science, New York, vol. xix, no. 488, pp. 328-329, June 10.

Seler, Eduard. Some remarks on Prof. C. Thomas's brief study of the Palenque tablet. Ibid., vol. xx, no. 493, pp. 38-39, July 15.

Thomas, Cyrus. The Palenque tablet. Ibid, vol. $\mathrm{xx}$, no. 496, p. 80, August 5.

\section{3}

Paso y Troncoso, Francisco del. Catálogo de la Sección de Mexico, Exposicion Histórico-Americana de Madrid. Madrid.

In tomo I, p. 25, is a notice of the expedition of Sres. Río de la Loza and Romero to the ruins. Sr. Río de la Loza made photographs of the structures, while Sr. Romero drew a plan of the Palace. Various pieces of stucco figures, pieces of pottery, and some human remains were gathered and brought away by the expedition. In tomo II, pp. 382-385, the plans and photographs are described, and on pp. 392-393 are listed the few antiquities collected by the commission at Palenque, which objects are now in the Museo Nacional of Mexico. 
Cresson, H. T. A row of hieroglyphs. Casa no. 2, Palenque. Science, New York, vol. Xxir, no. 546, pp. 30-31, 6 figs., July 21.

Valentini, Philipp J. J. Palenque hieroglyphs. Ibid., no. 550, pp. 90-91, August 18.

Thomas, Cyrus. Palenque hieroglyphs. Ibid., no. 553 , p. 135 , Sept. 8.

\section{4}

Brine, Lindesay. Travels amongst the American Indians, their ancient earthworks and temples, including a journey in Guatemala, Mexico and Yucatan, and a visit to the ruins of Patinamit, Palenque and Uxmal.

Captain, later Vice-Admiral, Brine visited Palenque in 1869. For his descriptions, see pp. 294-317, 3 pl., 1 fig.

\section{5}

Haebler, Karl. Die Maya-Litteratur und der Maya-Apparat zu Dresden. Centralblatt fïr Bibliothekswesen, Leipzig, XII Jahrgang, 12 Heft.

Valentini, Philipp J. J. Analysis of the pictorial text inscribed on two Palenque tablets. Proceedings American Antiquarian Society, Worcester, 24 pp., 2 pl., October.

See entry under 1896. 


\section{B I B L I O G R A P H I C NOTES}

Galindo y Villa, Jesus. Catálogo del Departamento de Arqueologia del Museo Nacional, Mexico. Primera parte, Galeria de Monolitos, Mexico.

Galindo y Villa, on p. 84, under numbers 272 and 273, describes two sculptures from Palenque as follows: "Ambas con caracteres mayas. La primera es una losa que tiene rota una esquina, labrada por sólo una de sus caras, de $0^{\mathrm{m}} 40$ de long. por $0^{\mathrm{m}} 26$ de lat . . . La segunda es un fragmento labrado sólo por una de sus caras: la superficie labrada tiene $0^{\mathrm{m}} 43$ de long., por $0^{\mathrm{m}} 18$ de latitud." The first sculpture is illustrated in our fig. 1.

\section{6}

Thompson, Edward H. Ancient tombs of Palenque. Proceedings American Antiquarian Society, Worcester, 6 pp., 1 folding pl., October.

Valentini, Philipp J. J. Analysis of the pictorial text inscribed on two Palenque tablets. Part II. Ibid., 21 pp., 2 pl.

See entry under 1895.

\section{6-1902}

Maudslay, Alfred P. Biologia Centrali-Americana; or contributions to the knowledge of the fauna and flora of Mexico and Central America. Edited by F. Ducane Godman and Osbert Salvin. Archaeology by Maudslay. London. Vol. IV, text, pp. 1-38, 3 fig.; vol. Iv, pl. i-xciii.

This report on the ruins of Palenque occupies the entire fourth and last volume of the monumental work 


\section{ON PALENQUE}

by Maudslay. Based on an expedition in 1890-1891, it contains plans of the ruins, and photographs and drawings of all the buildings and sculptures in situ, known at that time. Reviewed by Saville, M. H., in Monumental Records, New York, vol. I, no. 1, pp. 23-25, 2 ill., Oct.

\section{7}

Goodman, J. T. The archaic Maya inscriptions. In Biologia Centrali-Americana, op. cit., Appendix to Archaeology. London.

A treatment of the Palenque inscriptions is found on pp. 135-141. This fundamental work on the Maya calendar system is based on a study of the photographs and drawings furnished by Maudslay.

\section{7}

Hamy, E.-T. Galerie américaine du Musée d'Ethnographie du Trocadero. Choix de pieces archéologiques et ethnographiques décrites et publiées par le Dr. E.-T. Hamy. Paris. Two portfolios with plates and text.

In the second part, in pl. xxvii, no. 86, and on p. 54 are illustrated and described a terracotta vessel said to have been discovered in Palenque by L. J. Camacho in 1842. See fig. 6 . In pl. xxv, nos. 76 and 77 , and on p. 50 , Hamy figures a "katun et médaillon en stuc" from Palenque. No. 76 Hamy identifies as that sent from the ruins by Galindo and figured by him in 1834. No. 77 is a fragment of a stucco human face with mask, collected by Charnay, which was found on the floor of the celebrated Gallery of the Medallions.

Holmes, William H. Archeological studies among the ancient cities of Mexico. Part II, Monu- 


\section{B I B L I O G R A P H I C NOTES}

ments of Chiapas, Oaxaca and the Valley of Mexico, Field Columbian Museum, Anthropological Series, vol. I, no. I, Chicago, Feb.

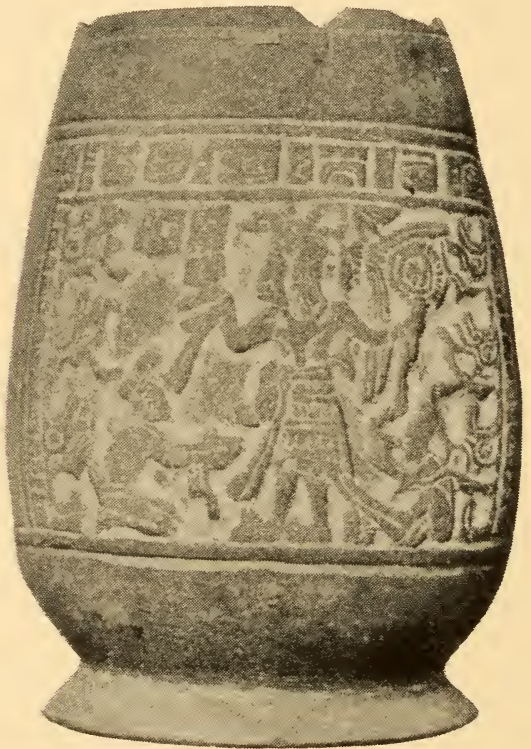

Fig. 6.-Vase in the Musée d'Ethnographie du Trocadero, Paris.

Palenque, pp. 151-209, pl. xix-xxv, fig. 42-67. Pl. xxiv is a sketch map, and pl. $x x v$ a panorama of the group. Professor Holmes was a member of the Armour expedition, and with E. H. Thompson was at Palenque in February, 1895. This is one of the most valuable studies of the architecture of Palenque. The panorama affords a splendid view of the grouping of the important temples and other edifices. 
Förstemann, E. Die Kreuzinschrift von Palenque. Globus, Braunschweig, Bd. Lxxir, no. 3, pp. 4549, 2 ill., July.

Translated into English and published under the title, The Inscription on the Cross of Palenque, in Bull. 28, Bureau of American Ethnology, pp. 547-555, pl. 41, 43, 44, Washington, 1904.

\section{$1897-1898$}

Saville, Marshall H. [Report of the Loubat expedition to Palenque.]

During the winter of 1897-1898, the late Duc de Loubat supplied the means for the American Museum of Natural History to send an archeological expedition to southern Mexico, under the terms of a concession granted to the Museum by the Mexican Government. The writer, accompanied by H. C. Humphries as engineer, left New York in October, planning to conduct work in the region of the upper Usumacinta river in the State of Chiapas, principally at the ruins of Menche, otherwise known as Lorillard City, but now better known as Yachilan. The expedition had probably the most complete equipment for prosecuting archeological work ever sent to tropical Mexico or Central America up to that time, including several tons of special paper purchased in Spain for making molds of sculptures. According to the terms of the concession the interests of the Mexican Government were to be represented in the field by the Inspector of Ancient Monuments, Leopoldo Batres. After reaching the City of Mexico and notifying the Department of Justice and Public Instruction of the writer's intention to work at Yachilan, he was obliged to wait more than a month for Sr. Batres to make his preparations for the journey. On our arrival in Chiapas, Batres refused to go to Yachilan, claiming that the site was within the Republic of Guatemala. Consequently the writer 


\section{B I B L I G R A P H C NOTES}

was obliged to change his plans entirely, and Palenque seemed to be the best place in which to carry on operations. The entire outfit therefore was transported with great difficulty to that site. Owing to constant rains, the road from Monte Cristo on the Usumacinta river to the village of Santo Domingo de Palenque was almost impassable. After getting the outfit to the ruins, Batres refused to take up his abode there, and remained in the village, making only one or two trips to the ruins during the six weeks the expedition remained in Chiapas. Owing to the fact that Batres did not like the climate, he placed every obstacle in the way of the investigation, even using his influence to prevent the hire of laborers. At that time labor was scarce, for in the neighboring mountain region there was great need of men to work in the coffee plantations; yet from the village it might have been possible to enlist a force of workmen sufficient to carry on important work. Nevertheless, it was found practicable to procure only two or three men to live at the ruins, except for several days when seven were employed, but these would not remain over night at the place, and it was not even possible to hire a cook. Mr. Humphries became ill and was obliged to return to the United States. Hence after remaining practically alone at Palenque for several weeks, with only a handful of men to clear the forest and to carry on excavations, all hope of working there was abandoned. Added to these difficulties was the almost continuous rain, for the rainy season that year continued well into January. On leaving Palenque I was obliged to wait eighteen days at Monte Cristo before the arrival of a river boat to take the party to Laguna, en route to Vera Cruz.

The meager results of these investigations at Palenque are set forth in the following report:

\section{HOUSE B, PALACE GROUP}

A general view of the site of the ancient cites of Palenque, looking west, is shown in fig 7 . The ruins are in the heavily forested hilly section beyond the plain. 
In clearing the vegetation from the roofs of the buildings surrounding the Western Court of the Palace, ${ }^{1}$ I discovered a much destroyed grotesque face or mask in stucco in the center of the façade on the western end of House B. The right side of the face had a large lobed ear-ornament, above which the remains of a winged ornament were found. A single perfect glyph placed close to it represents the sign for the day 1 Ahau. This edifice, like most of the Palenque buildings, once supported a wall-like structure rising from the center of the roof, called the roofcomb. Like all the others of the houses of the Palace Group, this had fallen, a portion of it in such a way as to make a bridge between Houses B and E, the two buildings being so close together that their projecting cornices almost touch each other (figs. 8, 9). Maudslay speaks of a bridge thrown across the very narrow space between the roof of this house (B) and that of House E, apparently not recognizing its true character. The fallen débris of the roof-comb resting on the roof of House E covered a small portion of the left side of the face. In order to uncover this portion of the face, two laborers were set to work removing tree roots, soil, and stones, a work much hampered by the presence of a large ants' nest.

The ear-ornament at the left side of the mask was well preserved by the fallen mass of masonry, but the corresponding single glyph as found on the other side of the mask had been destroyed. This should be the sign for the named month and could bear only one of four numerals, namely, $3,8,13$, or 18 . This face or mask has large eyes, and from what remained of the demolished nose it appeared to have been of the long uplifted type, the characteristic feature of the so-called "long-nose god." The greater number of analogous stucco masks on the Palenque buildings appear to be of this type. Above this mask, under the protecting

${ }^{1}$ The Palace Group is constructed in the form of an irregular structure 340 feet long by 260 feet wide and about 60 feet high. 


\section{B I B L I O G R A P H I C N O T E S}

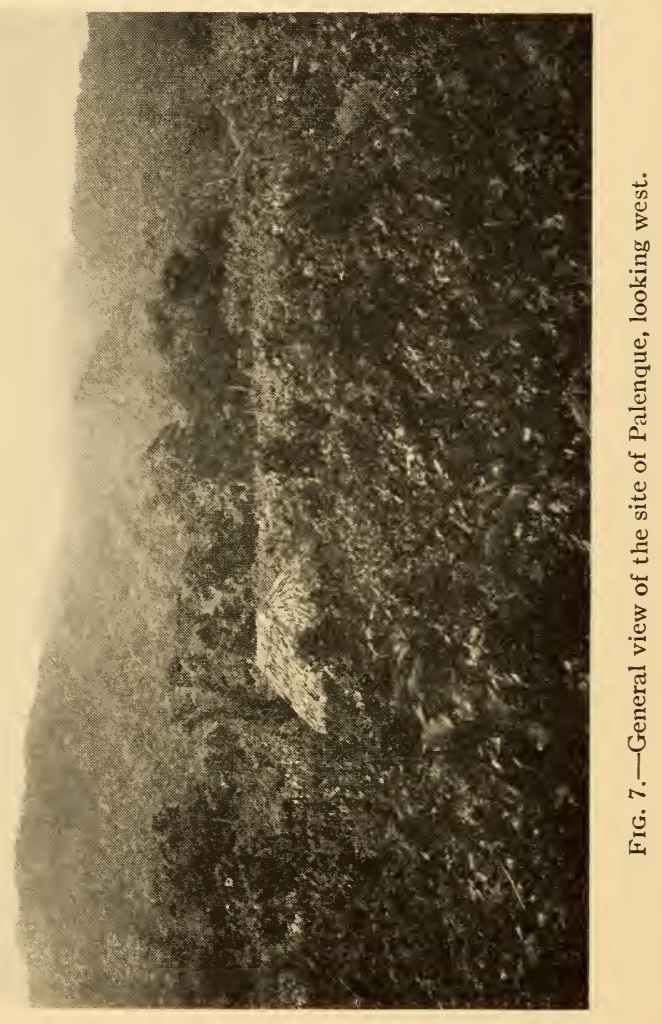


edge of the cornice, are traces of bright-red paint on the stucco surface of the wall. This partially preserved mask appears to have been the central one of three which decorated the façade, the other two having been totally destroyed.

In the débris close to the façade were found a number of interesting fragments of stucco figures as decorative ornaments, broken off by the falling of the masonry of the roof-comb. They were so brittle by the action of perpetual dampness that most of them crumbled when exposed. Some of the pieces still preserved their bright-red paint. One fragment represented a bird's head, and another was part of a human body painted red. Several curious little ball-like ornaments were found. Many little rods and strips of cut stone were scattered throughout the débris, and similar pieces projecting from the façade showed their purpose in holding the stucco decorations in place. One large fragment in the form of a torso, without trace of arms, simply showing the decoration of a garment, like the remains of the pier panels, was strengthened by the insertion of several such strips of stone, which insured solidity much better than the cords and sticks found in the stucco-work of the later Mayan city of Labna in Yucatan. In the upper part of the débris was a large slab which evidently had formed part of the roof-comb.

\section{HOUSE E, PALACE GROUP}

House $\mathrm{E}$ is one of the most interesting buildings of the Palace group, and is the only house in Palenque in which the outer roof is still in a relatively good state of preservation. Unlike practically all of the buildings at the site, this house shows no sign of having supported the lofty roof-comb, so characteristic of this group of ruins. Fig. 8, from a photograph made by the Loubat Expedition, is a view southeastward from the roof of House C; it shows the covering of thick white plaster, and the gentle pitch of the roof with a peculiar slight bevel near the center. This type of 


\section{B I B L I O G R A P H I C N O T E S}

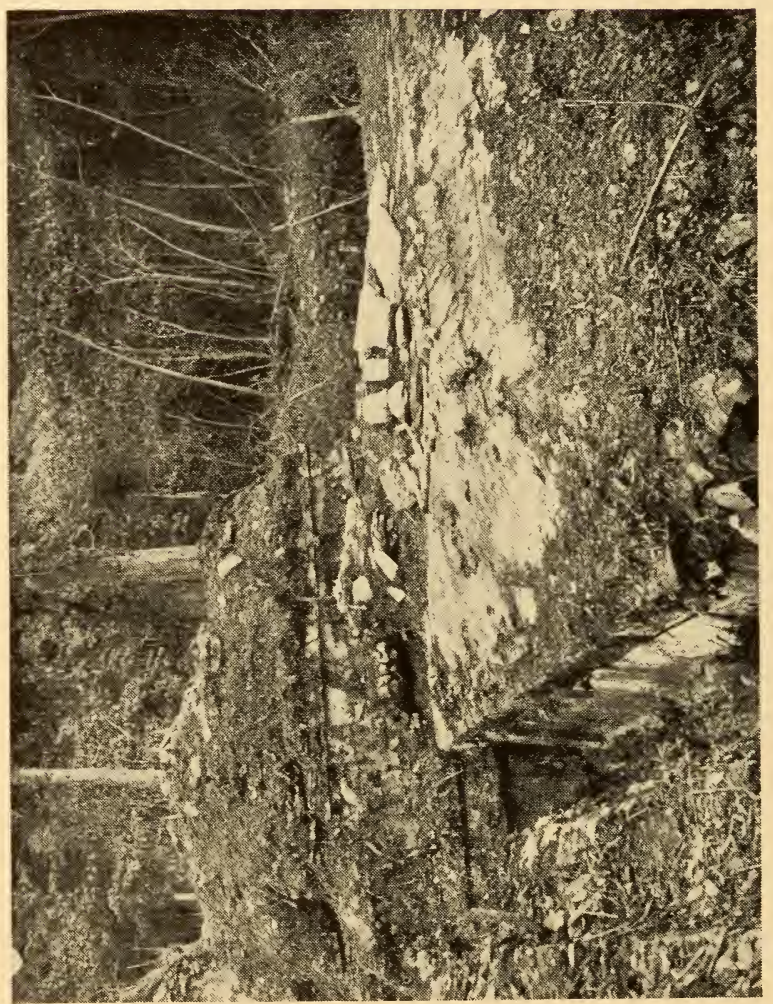

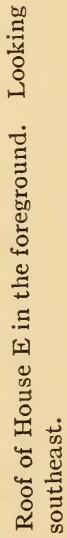

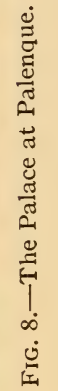




\section{ON PALENQUE}

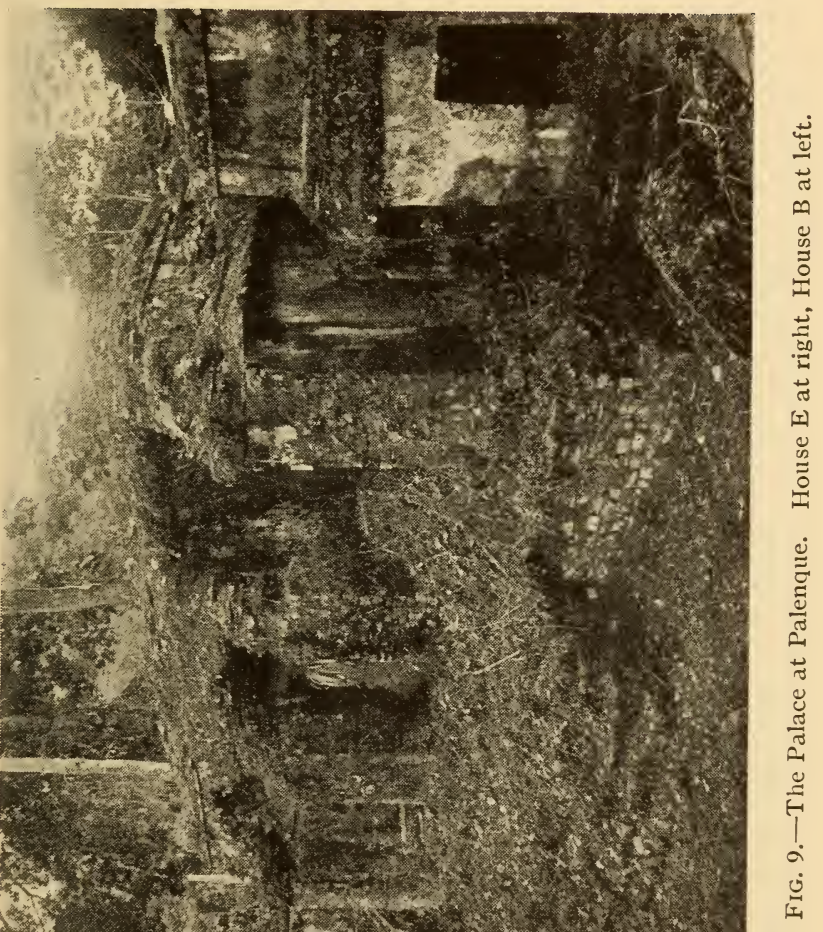




\section{B I B L I O G R A P H I C N O T E S}

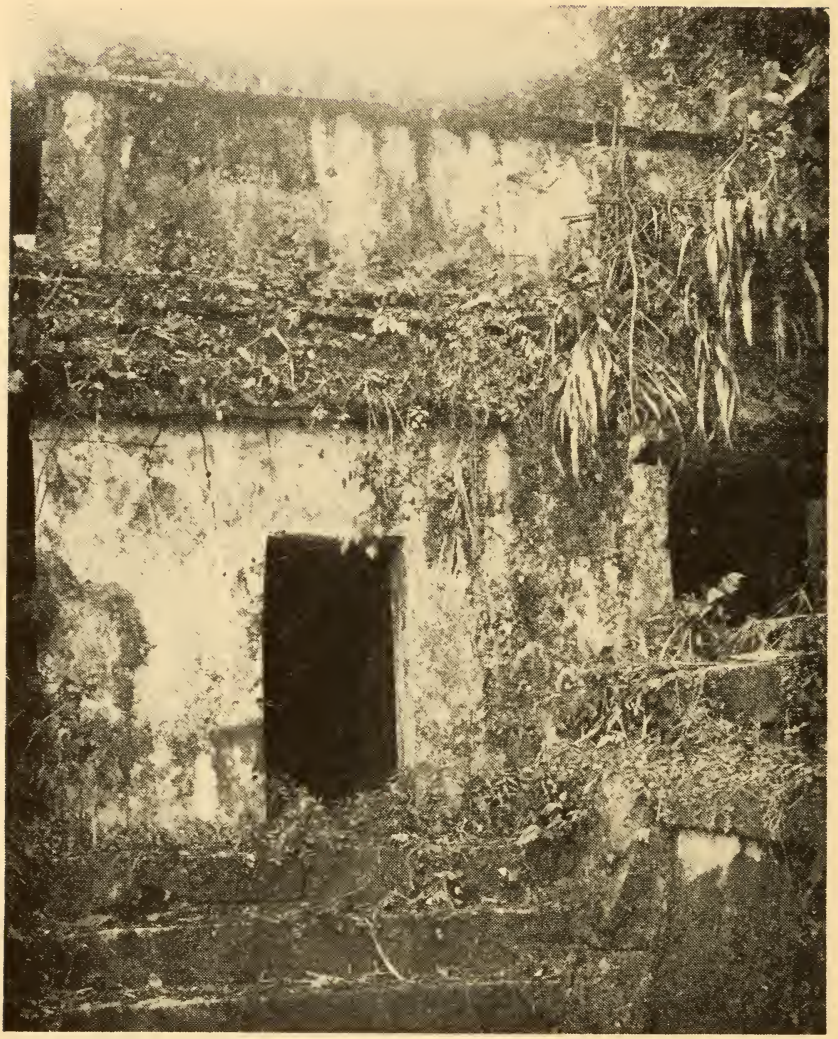

FIg. 10.-The Palace at Palenque. House $\mathrm{C}$ at right, House $\mathrm{E}$ at left. 


\section{O N P A L E N Q U E}

roof, unusual in Palenque, the very slightly sloping façade front, and the fact that the foundations of Houses B and C were built against its walls (figs. 9, 10), indicate, as recognized by both Holmes and Maudslay, that it was undoubtedly one of the earliest buildings of the Palace group.

The structure is further noteworthy for the stucco ornaments which decorate the northern end of the eastern corridor-like chamber. A wall extends lengthwise in the middle of the house, separating the two long parallel corridor-like chambers. In the western room there is set in this wall an oval sculptured slab with two seated human figures, the seat of the principal figure being in the form of a double-headed animal; above the figures are two short hieroglyphic inscriptions. Above this slab also, below the spring of the roof, is a long inscription painted in black, which was copied and published for the first time by Maudslay.

In the southern end of the same corridor is an opening in the floor, from which descends a stairway leading to one of the three subterranean passages which communicate with the three known subterranean corridors in the southern part of the structure. There is every reason to believe that there is a series of chambers in the substructure of the northern section of this group. The Loubat Expedition made a number of sounding tests, and found several places where the hollow sound seemed to indicate the existence of an underground chamber, but was forbidden by the Inspector of Monuments from making any excavations of this nature. Undoubtedly the majority of the substructures of temples and other edifices are honeycombed with corridors and rooms.

Maudslay states that the walls of this house appear to have been ornamented inside and out with painted designs and inscriptions, and some of the decorations can still be traced on the outside of the western wall. Dr. and Mrs. Seler laboriously copied all of the visible paintings on both the outer and the inner walls. These are published in Seler's study (1915). 


\section{TOMB NORTHEAST OF THE PALACE GROUP}

The entrance of a small tomb or burial cist was accidentally discovered in the forest northeast of the Palace, across the river, eastward from the bridge and outside of the limits of Maudslay's map. The entrance had been previously opened, but on sounding the floor it seemed as if there might be another chamber beneath. In order to facilitate this search, a clearing was made around the front and top of the tomb, that the roof stones might be removed. This small burial chamber was found to have been built on a shelf cut out of the bedrock on the northern side of a low mound or hill. The top of the eminence served as a base for a series of stone buildings now entirely in ruins and covered with dense forest growth.

The tomb in question was constructed by laying two flat stones for a floor; two stones each formed the side walls, and three stones were placed across for the flat roof. The inner end of the chamber was placed against the slightly sloping bedrock. Against the ledge and resting on the side wall was a pole-shape stone, serving at the point as a roof stone. It is of the same material as that of the tablets in the buildings, the roof cap-stones, and others used in the construction of the edifices. It is probable that these stones were quarried in rather thin slabs, the cleavage making it necessary only to smooth the surfaces and to dress the edges. The pole-like stone in this roof shows well the pecking or hammering to shape it roughly with a stone chisel or celt.

The floor of the tomb was covered with about half an inch of earth, but as the outer northern end had been opened, this soil may have washed in from above. The floor stones when raised were found to rest on the ledge rock, so that the only result of the examination was the knowledge gained concerning the construction of this class of burial chambers. The side wall stones were somewhat out of place, and the top of the roof was covered with an average of one foot of stones and 
earth closely packed, over which was about six inches of vegetal débris. In the lower layer were found two fragments of obsidian knives, a sherd of an ordinary earthen plate, and a broken grinding-stone. The dimensions of this tomb are: Length, six feet two inches; width, one foot two inches, height ten inches,

\section{SMALL SEALED BUILDINGS, PERHAPS TOMBS}

South of the Palace group, ascending the Michol river for about a quarter of a mile, at the very outskirts of the city, is a group of low-chambered mounds, and some small stone structures still standing. These little buildings are closed or sealed, and the group is undoubtedly the place of burial of ancient priests. With only three men I spent a number of days endeavoring to force an entrance into one of these chambers, but without success. The incessant rains and lack of sufficient workmen made it necessary, with great reluctance, to discontinue the effort.

The present-day Indians of Palenque speak a dialect of the Maya language, Putun. In fig. 11 is reproduced a photograph of a woman of pure blood reputed to be one hundred years old. It was taken by the author in the village of Palenque, December 1897.

\section{THE BATRES REPORT}

The Inspector of Monuments, Leopoldo Batres, made a report of the explorations at Palenque to Sr. Don Joaquin Baranda, Minister of Public Instruction of Mexico. This report follows:

"In obedience to the terms of clause 3 of the permit granted to Mr. Marshall H. Saville, I proceeded to the ruins of Palenque, arriving at the village of Santo Domingo de Palenque on December 5th last [1897].

"Between that day and the 15th of the same month I visited the ruins repeatedly in company with the concessionaire, Mr. Saville, in the meantime setting a gang of men at work to clear the vegetation from the eastern side of the pyramid on the top of which the Palace is situated, and also from the roofs of the ruins. 


\section{B I B L I O G R A P H I C NOTES}

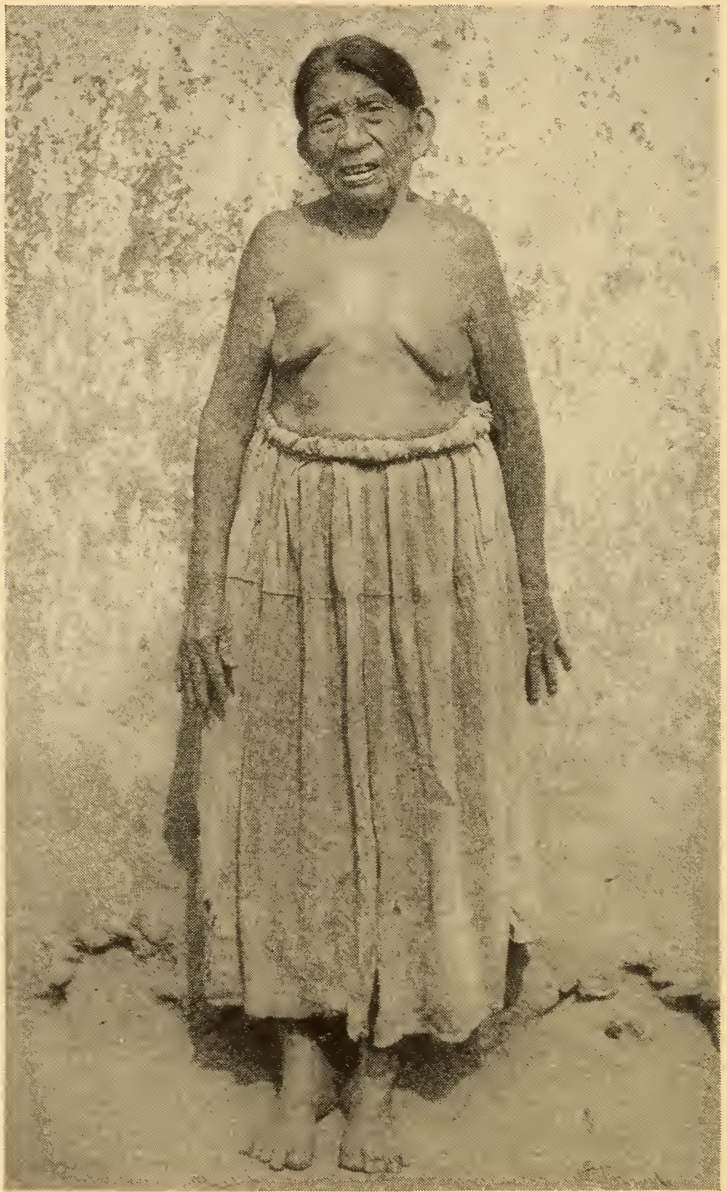

FIG. 11.-Putun Indian woman of the village of Palenque, reputed to be a centenarian. 
"This work was rendered difficult by the constant rain and the scarcity of laborers; yet with great energy Mr. Saville began to conduct his excavations. On the 16 th he opened one of the sepulchers situated to the southeast of the Palace, on the left bank of Baños creek, but he found nothing in it but some damp earth. On the 20th, the same gang of workmen cleared the western side of the pyramid which forms the roof of the apartments or oratories on the south of the principal court of the Palace, during which operation fragments of stucco were discovered, as well as one of the large masks decorating the four sides of the pyramid that covers the roof. On the 21st Mr. Saville made some excavations in the destroyed edifice situated some six hundred meters northwest from the Palace, and he continued these excavations on the $23 \mathrm{~d}$. On the 21 st also, Mr. Saville sent a gang of workmen to open a sepulcher situated northwest from the Palace, but again nothing was found in it.

"From December 23d to January 3d, Mr. Saville made his last attempts at exploration, and amongst other things, opened a sepulcher on the right bank of Baños creek, without obtaining any result. Mr. Saville was by this time fully convinced that he would meet with no success in his explorations, owing to a variety of adverse circumstances, the chief of which was his conviction that the antiquities of which he was in search have been completely destroyed by moisture. He therefore decided to abandon his explorations, which he did on January 4th.

"All of which I have the honor of laying before you as the result of Mr. Saville's explorations in the ruins of Palenque."

(Signed) LEOPOLDo BATRES.

\section{8}

Holmes, William H. Palenque. Monumental Records, New York, vol. I, nos. 5 and 6, pp. 57-67, 13 ill., May and June. 
An editorial note states that "The above article is reprinted from Archæological Studies Among the Ancient Cities of Mexico .... part of the text and illustrations being omitted to bring it within the limits of Monumental Records."

\section{9}

Förstemann, E. Aus dem Inschriftentempel von Palenque. Globus, Braunschweig, Bd. Lxxv, Heft 5, pp. 77-80, 29 figs.

Translated into English and published under the title, The Temple of the Inscriptions at Palenque, in Bull. 28, Bureau of American Ethnology, pp. 575-580, Washington, 1904.

Förstemann, E. Drei Inschriften von Palenque. Ibid., Bd. Lxxvi, Heft 11, pp. 176-178, 9 figs.

Translated into English and published under the title, Three Inscriptions of Palenque, in Bull. 28, Bureau of American Ethnology, pp. 583-589, fig. 113, Washington, 1904.

Maudslay, Anne Cary, and Alfred P. A glimpse at Guatemala. London.

For Palenque see pp. 22t-229, 6 pl., 2 ill.

\section{2}

Förstemann, E. Die Kreuzinschrift von Palenque. Zeitschrift für Ethnologie, Berlin, Bd. xxxıv, pp. 105-121.

Chavero, Alfredo. Calendario de Palemke. Los signos de los dias. Memoria presentada al XIII Congreso de Americanistas. Mexico. 42 pp., 4 ills.

See title under 1905. 


\section{3}

FöRstemann, E. Zusammenhang zweier Inschriften von Palenque. Globus. Braunschweig, Bd. LxxxiII, Heft 18, pp. 281-284.

\section{5}

Chavero, Alfredo. Palemke calendar, the signs of the days. Proceedings of the International Congress of Americanists, 13th Session, New York, 1902, Easton, Pa., pp. 41-65.

With the exception of the notes in Spanish, this paper is an English translation of the item under 1902.

\section{7}

EL Capitan Dupaix y las ruinas de Ococingo y Palenque. Anales del Museo Nacional, Mexico, segunda época, tomo IV, entregas 1-2, pp. 1-23.

This report, copied in 1906 from the original manuscript preserved in the Episcopal Archives of Chiapas, relates to investigations in regard to Guillermo Dupaix and his exploration of the antiquities of Ococingo and Palenque in 1805-1807. Dupaix was suspected of treason to the Viceroy Iturrigaray, and the exploration of the ruins was said to have been a ruse to cover plans for some foreign invasion. From this document it is learned that Dupaix was acquitted of the charge and that aid was promised him for the continuance of his researches.

\section{8}

L. T. O. La cruz de Palenque. Revista Nacional, Mexico, año I, núm. 2, June 29. 


\section{B I B L I O G R A P H I C NOTES}

A notice of the arrival in the City of Mcxieo of the first or left-hand section of the Tablet of the Cross, brought from the ruins of Palenque by order of Minister D. Justo Sierra to complete the entire tablet in the Museo Nacional of Mexico. A photograph shows two corners of the tablet damaged in transportation. The central panel was for a long time in the city; the third or right-hand panel was returned to Mexico in 1908 by the United States National Museum.

Batres, Leopoldo. Las ruinas de Palenque. Informe rendido a la Secretaria de Justicia é Instrucción Pública en 28 de Enero de 1898. Mexico. 21 pp., 2 pls.

\section{0}

Rickards, Constantine George. The ruins of Mexico. London. Vol. I, Ruins of Palenque, text pp. 3-6; 33 mounted photographs of Palenque, with titles on pp. 8-18.

\section{1}

Saville Marshall $\mathrm{H}$. The work of the Loubat expedition in southern Mexico. Paris, March 23. $4 \mathrm{pp}$.

This leaflet, printed in Paris by the Duc de Loubat, embodies a brief report to the patron of the expedition, relating to the difficulties the leader experienced with Leopoldo Batres, the Mexican Inspector of Monuments. Owing to lack of coöperation on the part of the Inspector the plan for the work of the Loubat Expedition at Chiapas and Palenque could not be consummated. See entry under 1897-1898. 


\section{ON P A L E N Q E}

Seler, Eduard. Ein Brief aus Mexiko (Palenque). Zeitschrift für Ethnologie, Berlin, Bd. XlıI, pp. 310-315, 3 ill.

Batres, Leopoldo. Basementos de las ruinas de Palenque. Mexico.

Contains a page of text entitled "La Verdadera forma de las Bases de los Monumentos de los Edificios de Palenque," with a panorama based on that of Holmes, but containing a restoration of the substructures of the buildings, etc.

\section{2}

Sandberg, Harry C. Ancient temples and cities of the New World. Palenque. Bulletin of the Pan American Union, Washington, pp. 344-360, map, 10 ills., March.

\section{3}

Spinden, Herbert Joseph. A study of Maya art, its subject matter and historical development. Memoirs of the Peabody Museum of American Archaeology and Ethnology, vol. vi, Cambridge.

Morlex, Sylvanus Griswold. Archaeological research at the ruins of Chichen Itza, Yucatan. Extracted from "Reports upon the present condition and future needs of the science of anthropology," presented by W. H. R. Rivers, A. E. Jenks, and S. G. Morley, at the request of the Carnegie Institution of Washington, pp. 61-91. Washington. [n.d.] 


\section{B I B L I G R A P H I N T E S}

Mention of Palenque (pp. 64-65) is made in connection with the notice of the cities forming a group established by the Maya shortly after the beginning of the Christian era. On p. 87 is a brief list of studies relating to the ruins.

\section{5}

Seler, Eduard. Beobachtungen und Studien in den Ruinen von Palenque. Abhandlungen der Königl. Preuss. Akademie der Wissenschaften, Berlin, Jahrgang 1915, 129 pp., map, 19 pl., 146 figs.

Professor and Mrs. Seler spent three weeks at the ruins late in summer of 1911 . The present study presents much new material, especially on the stucco ornaments and paintings found in the Palace, here illustrated for the first time.

\section{7}

Morlex; Sylvanus Griswold. The rise and fall of the Maya civilization in the light of the monuments and the native chronicles. Proceedings of the Nineteenth International Congress of Americanists, Washington, 1915, pp. 140-149, 11 pl., Washington.

In pl. III, $c$, is reproduced a painting of the Palenque site by Carlos Vierra. Morley discusses the occupancy of Palenque, based on the range of known dates, during the so-called Old Empire epoch. According to his correlation of the dates, they fall between the years 360 to 420 A.D.; but he states that the question yet remains to be determined, as the art and architecture of the city are such as hardly to have been achievable before one hundred years later. Morley believes that it may be possible to explain this discrepancy by the presumption that certain tablets may have been designed for earlier buildings. 


\section{O N PALENQUE}

\section{8}

Mcrley, Sylvanus Griswold. Archeology. Extracted from Year Book No. 17 of the Carnegie Institution of Washington (for the year 1918).

On pp. 275-276 Morley records a visit to the ruins and recounts the discovery of "two new initial series, one on the left-hand pier of the façade of the Temple of the Sun, and the other on the back wall of the outer chamber of the Temple of the Beau Relief. Unfortunately both were entirely destroyed save for their introducing glyph, and decipherment was impossible."

\section{0}

Morley, Sylvanus Griswold. The inscriptions at Copan. Publication No. 219, Carnegie Institution of Washington.

Contains numerous references to Palenque.

\section{1}

Pérez Rubin, Luis. Mejico en 1521. Raza Española, Madrid, a ño III, núm. 33, pp. 10-19, Sept.

The plate opposite p. 12, fig. 1, illustrates a basrelief from Palenque, with the caption, "The god Quetzalcoatl, ruins of Palenque."

\section{2}

HARRIS, IV. R. Parent lands of our Algonquins and Hurons. Thirty-third Annual Archaeological Report, Toronto.

On pp. 42-44 is a rhapsody describing an evening spent alone at the ruins. 
1923

Panagos, Ranulfo. Las famosas ruinas de Palenque. Orto, Organo de la Sociedad de Estudiantes Chiapanecos, Mexico, año I, núm. 4, Feb.

Joyce, T. A. Guide to the Maudslay collection of sculptures, casts and originals from Central America, British Museum. London.

The casts of Palenque sculptures are described with an interpretation of the dates on pp. 74-79. Pl. vI is the Tablet of the Sun, and pl. VII is Maudslay's photograph of the east court of the Palace, showing the tower.

Blom, Frans. Las ruinas de Palenque, Xupa y Finca Encanto. Manuscript report to the Dirección de Antropologia, Secretaria de Agricultura y Fomento, Mexico. 232 pp., 143 figs., 2 folded plans.

An important report of several months' work of exploration and excavation, not yet published.

\section{4}

Spinder, Herbert Joseph. The reduction of Mayan dates. Papers of the Peabody Museum of American Archcology and Ethnology, Harvard University, vol. vi, no. 4, Cambridge.

In this important book (pp. 168-175, 181-208) Spinden discusses at length the various inscriptions at Palenque, correlating the dates with those of the year, month, and day of our calendar. 
1925

Joyce, T. A. An example of cast gold-work discovered in Palenque by De Waldeck, now in the British Museum. Proceedings of the Twentyfirst International Congress of Americanists, The Hague, pt. I, pp. 46-47, 2 ill.

Ricketson, Oliver. Burials in the Maya area. American Anthropologist, Menasha, IVis., n.s., vol. 27, no. 3, pp. 381-401, July.

On pp. 383-386 the author treats of the tombs discovered at Palenque as noted by Waldeck, Maudslay, Thompson, and Blom.

\section{6}

Totten, George Oakley. Maya architecture. Washington.

Palenque is treated on pp. 74-91, pls. $\mathrm{xx}-\mathrm{xxviii}$. On pl. xxviii is an illustration of the model of the Temple of the Sun on exhibition at the American Museum of Natural History, New York.

\section{6-1927}

Blom, Frans. Tribes and temples. A record of the expedition to Middle America conducted by The Tulane University in 1925. New Orleans. 2 vols.

In this work Blom publishes a résumé of his report (see item under 1923) on the Palenque ruins, in vol. I, chap. vii, pp. 169-189, pl. i-ii, figs. 127-163, and a "rough plan of Palenque ruins in 1923." He states that the ruins cover about 16 square kilometers in extent. This report is highly important. 
Beyer, Hermann. Dos fechas del palacio de Palenque. Revista Mexicana de Estudios Historicos, Mexico, tomo I, núm. 1, pp. 107-114, 5 figs., Enero y Febrero.

This study relates to the two tablets illustrated in our figs. 2 and 4 . Beyer has rectified the drawing of the first two glyphs in each tablet as published by Dupaix which corresponds to the corrections made in our figures.

Thompson, J. Eric. The elephant heads in the Waldeck manuscripts. Scientific Monthly, Lancaster, Pa., pp. 392-398, 5 figs., Nov.

Illustrates several water-color paintings made by Waldeck in 1832-1833 at Palenque, in the Ayer collection, Newberry Library, Chicago. Three of these, as represented by Waldeck, apparently depict elephant heads made in stucco. Inasmuch as Waldeck's drawings and paintings have long been known to be inaccurate, in the light of the many photographs made at Palenque during the last seventy years, they must be accepted as being purely fanciful, as neither Captain Caddy, nor Stephens and Catherwood, who were at Palenque eight years after Waldeck's visit in 1832, found anything of the sort in the ruins.

\section{8}

Reygadas Vértiz, José. Estado actual de los principales edificios arqueologicos. Contribucion de Mexico al XXIII Congreso de Americanistas. Secretaria de Educacion Publica. Mexico.

Palenque is described by Sr. Reygadas Vértiz on pp. 161-166, with 9 ill. 


\section{O N P A L E NQUE}

Marquina, Ignacio. Estudio arquitectonico comparativo de los monumentos arqueologicos de Mexico. Contribucion de Mexico al XXIII Congreso de Americanistas. Secretaria de Educacion Publica. Mexico.

Palenque is treated on pp. 46-50, with 5 pp. of plans. Palacios, Enrique Juan. En los confines de la selva Lacandona. Exploraciones en el Estado de Chiapas, Mayo-Agosto, 1926. Contribucion de Mexico al XXIII Congreso de Americanistas. Secretaria de Educacion Publica. Mexico.

A visit to Palenque is described in chapter xviii, pp. 171-175, figs. 128-131.

Roys, Ralph L. Recent development in Maya research. El Palacio, Santa Fe, N. Mex., vol. xxv, nos. 21-22, pp. 341-357, Nov. 24, Dec. 1. Mentions Blom's work at Palenque. 


\section{AUTHORS}

Baily, J., 1823

Bancroft, Hubert Howe, 1882

Bandelier, Adolphe F., 1881

Batres, Leopoldo, 1908, 1911

Beyer, Hermann, 1927

Blom, Frans, 1923, 1926-1927

Boddam Whetham, J. W., 1877

Brasseur de Bourbourg, C. É., 1866, 1866-1867

Brine, Lindesay, 1894

Brinton, Daniel G, 1885

Bustamante, Miguel, 1835

Cabrera, Paul Felix, 1822

Caddy, John Herbert, 1840

Calderón, José Antonio, 1784

Castañeda. See Dupaix, 1834

Catalogue, 1883

Catherwood, Frederick, 1844, 1854

Charnay, Désiré, 1863, 1880, 1881, 1884, 1885, 1887

Chavero, Alfredo, 1902, 1905

Cochelet, Adrien, 1832

Corroy, François, 1832

Cresson, H. T., 1893

Dupaix, Guillelmo, 1834, 1907

Estacheria, José de, 1784

Förstemann, E., 1897, 1899, 1902, 1903

Galindo, Juan, 1831, 1832, 1833, 1834. See Dupaix, 1834

Galindo y Villa, Jesus, 1895

Gondra, I. R., 1837 


\section{ON PALENQUE}

Goodman, J. T., 1897

Grosse, Ernst, 1891

Haebler, Karl, 1895

Hamy, E.-T., 1897

Harris, W. R., 1922

Holmes, William H., 1897, 1898

Humboldt, $A$. von, 1810

Joyce, T. A., 1923, 1925

Juarros, Domingo, 1808

Kingsborough, Lord, 1830-1848

L. T. O., 1908

Lenoir, Alexandre. See Dupaix, 1834

Maler, Teobert, 1879, 1884

Marquina, Ignacio, 1928

Maudslay, Alfred P., 1896-1902, 1899

Maudslay, Anne Cary, 1899

Morelet, Arthur, 1857, 1871

Morgan, Lewis H., 1880, 1881

Morley, Sylvanus Griswold, 1913, 1917, 1918, 1926

Ober, Frederick A., 1884

Ordoñez y Aguiar, Ramón de, 1784

Palacios, Enrique John, 1928

Panagos, Ranulfo, 1923

Paso y Troncoso, Francisco del, 1893

Peñafiel, Antonio, 1890

Pérez Rubin, Luis, 1921

Polakowsky, H., 1889

Rau, Charles, 1879

Reygadas Vértiz, José, 1928

Rice, Allen Thorndike, 1880 


\section{B I B L I O G R A P H I C N O T E S}

Rickards, Constantine George, 1910

Ricketson, Oliver, 1925

Rio, Antonio del. See Cabrera, 1822; Dupaix, 1834 Rochefoucauld, F. A. de la, 1888

Rosny, Leon de, 1882

Roys, Ralph L., 1928

Sandberg, Harry C., 1912

Saville, Marshall H., 1897-1898, 1911

Seler, Eduard, 1892, 1911, 1915

Spinden, Herbert Joseph, 1915, 1923

Squier, E. George. See Morelet, 1871

Stephens, John Lloyd, 1841, 1854

Thomas, Cyrus, 1885, 1892, 1893

Thompson, Edward H., 1896

Thompson, J. Eric, 1927

Totten, George Oakley, 1926

Valentini, Philipp J. J., 1893, 1895, 1896

Viollet-le-Duc, E. E., 1866-1867

Waldeck, Frederick, 1838, 1865, 1866

Warden, David B., 1825 


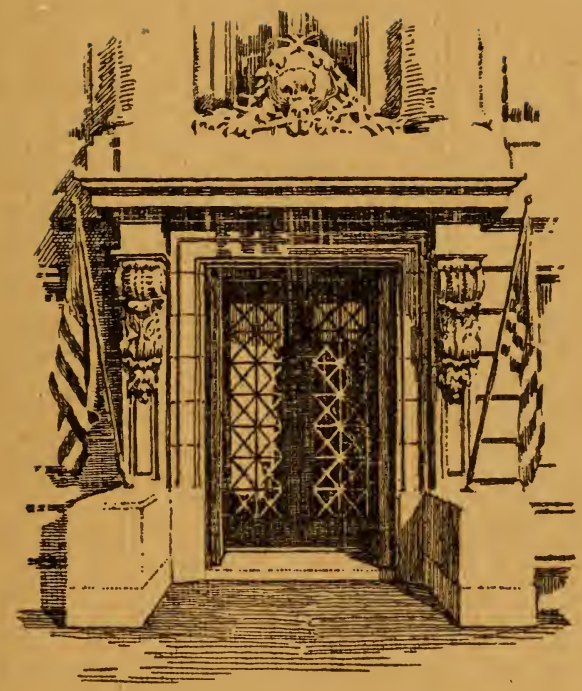


SMITHSONIAN INSTITUTION LIBRARIES

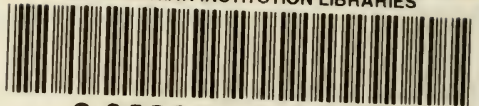

39088011428836 